\title{
Distributed Leadership and Empowerment Influence on Teachers Organizational Commitment
}

\author{
Hairuddin Mohd Ali \\ International Islamic University Malaysia (IIUM) \\ Email: hairuddin@iab.edu.my \\ Salisu Abba Yangaiya \\ Isa Kaita College of Education Dutsinma, Katsina State, Nigeria \\ Email: yangaiya@yahoo.com
}

Doi:10.5901/ajis.2015.v4n1s1p73

\begin{abstract}
The purpose of this study is to examine the influence of school distributed leadership (DL) on teachers' organizational commitment (TC) and to investigate if teachers' empowerment (TE) mediates the relationship between distributed leadership and teachers' organizational commitment. The study distributed 750 questionnaires to the sampled respondents out of which 550 or $73 \%$ were returned. However, after excluding questionnaires with serious missing information 499 usable returned questionnaires were used for this study. The study used SPSS and AMOS (versions 16.0) to analyze the data collected. The findings indicate that school distributed leadership has considerable effect on teachers' organizational commitment (standardized coefficient .39). The study also proved that teacher empowerment considerably mediates the relationship between distributed leadership and teachers' commitment (standardized coefficient .26). As for the implications, the findings of this study bring to the fore the need for head teachers, zonal directors and other stakeholders to find more means of distributing leadership in secondary schools in order to enhance teachers' commitment and empowerment. The study is one of the few studies conducted to investigate the influence and the relationship of distributed leadership on teachers' organizational commitment and the mediating role of teachers' empowerment on distributed leadership and teachers' commitment, in Katsina state in particular and Nigeria in general.
\end{abstract}

Keywords: Distributed leadership, Teacher commitment, teacher empowerment, principal component analysis, confirmatory factor analysis.

\section{Introduction}

Defining leadership from one's faith perspective almost certainly triggers substantial reactions from certain quarters. Besides Bass's theory of leadership (Bass, 1985a, 1985b, 1990; Bass and Avolio, 1993), the Muslims in particular are convinced that Prophet Adam (AS) (and his wife Eve) were dispatched to earth by "Allah" (God) as khalifah which is synonymous to successor, steward, trustee, viceroy and guardian whereby all of these characteristics are recognized to be the attributes of excellent leadership as far as Islamic faith is concerned. This is justified by a verse from Al Quraan,

"Behold thy Lord said to the angels: 'I will create a khalifah on earth.' They (the angels) said 'Will You place therein one who will make mischief and shed blood? Whilst we do celebrate Your praises and glorify You with praises and sanctify Your (Name)?' God said: 'I know what you know not." (Quran 2:30)

In contrast, the human kind history and knowledge believe that there are three basic ways of becoming a leader (Stogdill, 1948, 1974 and 1982) particularly originated from trait theory, great event theory and the most welcomed, transformational or process leadership (Stogdill, 1948, 1974 and 1982; and Bass, 1990). In the latest development, Eacott (2007, 2008 and 2010), believes that the knowledge and scholarship of leadership term is perhaps becomes the central concept of interest in every sectors including educational administration. Pursuant to this argument, leadership has long been claimed as a major determinant to the success, achievements or failure of organizations (Bass, 1990, 1993 and 1985). This assertion is more prominent in educational setting due to countless challenges, namely, the students population explosion, the organizational bureaucracy and complexity, and teacher burnout are among others. Hence, this paper makes a stance that leadership is defined as an act of influencing the activities of all members of an organization towards goal setting and goal achievement (Adaeze, 2004 and Northhouse, 2007). 


\section{Reason for School Distributed Leadership (DL)}

Gronn (2000, 2002a, 2002b, 2003 and 2009) stresses that there has been increasing dissatisfaction with the domination of the concept of the "focused" or "solo" leader in leadership studies. If the traditional leadership model focused only on one individual, distributed leadership suggests that the aggregate leadership is dispersed among the members of the organization. House and Aditya (1997) mentioned, leadership involves collaborative relationships that lead to collective actions such as distributed leadership can be delegated, co-leadership or peer leadership. Despite the use of term shared or collegiate, distributed leadership is perhaps the most common term used on "collective leadership". Gronn (2000, 2002a, 200b, 2003 and 2009) continues to argue that the study of distributed leadership offers an exciting window of opportunity for qualitative, longitudinal field studies to explore contextual variables influencing distributed leadership. As a consequence, more studies beginning to move towards and beginning to support the role of the distributed as opposed to solo leadership (Spillane et. al 2004; Spillane, 2006 and 2001; Harris, 2007, 2008a; 2008b, Leithwood, 2007) and the literature recognized that the most contemporary interpretation of distributed leadership theory is the one that is provided by Spillane (2001, 2004 and 2006).

Previously, leadership in school was regarded as the responsibility of a valiant, solo or courageous leader, who is able to direct, lead and influences the future direction of the school. Nevertheless, to Hartley (2007 and 2010), leadership in school setting in particular has changed from transformational and traditional setup to distributed leadership. Efforts to better understand how leadership influences successful schools and student performance are now being extended from individual leadership (of Principal) to distributed and collective leadership approach (Mascall, Leithwood, Straus and Sacks, 2008). As proposed by Harris (2004, 2007, 2008a, 2008b), in schools, as different people seek and are tacitly or openly granted leadership functions, a dynamic pattern of distributed leadership gradually takes over. There must be an enormous reason for this and as claimed by Hulpia and Devos (2010a), the challenge that the schools are facing probably can be overpowered through the internalization and practice of distributed leadership.

However, there should be a reciprocal principle here where it should be stressed that before a school can obtain committed teachers, those at the helm (leaders and administrators) must ensuring the presence of conducive environment, through the provision of needed facilities, provision of positive climate, enhancing capacity building, involving teachers in decision making on issues related to teaching and learning among others.In other words, the leaders must carry out the necessary changes in the way things are being done in their respective schools and this wish list is rather only a dream wants. In schools of today, we are very much less fortunate as the heroic leaders cannot effectively change the environment and hence not able to realize the teachers' commitment (Angelle, 2010). Thus, it is pertinent that the leadership is shared by all organizational members for the betterment of the organization.

Harris $(2004,2007,2008 \mathrm{a}, 2008 \mathrm{~b})$ also noted that the belief of changing schools through the effort of an individual leader is quickly changing because, although good leaders with exceptional vision and action are available, but unfortunately they are not in large supply to take care of the demands and challenges of today's schools. Due to this, a single and "stand-a-lone" leader cannot effectively operate as efficient as if the roles are distributed across members of his/her organization. It is however gladdening that those who study and those who practice the art of leadership have started looking at leadership as a collective effort of all members of the organization. This is what this paper is looking at, that is the practice of distributed leadership. Furthermore Spillane et al. $(2001,2004)$ and Spillane $(2006)$ noted that by stressing the aspect of leadership practice and by assuming that leadership practice is the product of interaction between leaders, followers and their situations, distributed leadership perspective provides another way of viewing leadership in our schools.

Hulpia and Devos (2010a), recognize distributed leadership as the sharing of leadership functions among the leadership teams, which is a group of people within the organization with leadership roles. Distributed leadership pave the ways for teachers to be involved in decision making, especially on issues related to teaching and learning. Considerable numbers of studies reveal a positive relation between teachers' participation in decision-making processes and their organizational commitment (Hulpia and Devos, 2010b). It is worth noting also that distributed leadership encourages social interaction between the leaders as well as followers and that social interaction contributes a lot in enhancing teacher commitment, teacher effectiveness and student engagement (Leithwood and Jantzi, 1999, 2000a, 2000b; Leithwood et. al., 2006, 2007 and 2010). They also note that that teacher leadership practices has a significant effect on student engagement (achievement). Another study proved that there is a positive relationship between the teachers involving in decision making and ranges of student outcomes such as student motivation and self efficacy and educational outcome (Mujis, 2011). 


\section{Teacher Organizational Commitment (TC)}

Organizational commitment implies that the members of an organization actually incline to be the main players and hence play their active roles in their organization. As a result, these certainly have positive impacts on activities in the organization such as sense of possessing high status, willing to contribute and contribute beyond what is expected out of them (Bogler and Somech, 2004). Furthermore, Mowday, Steers, and Porter (1979) viewed organizational commitment as the relative strength of an individual's identification and involvement in a particular organization.

Particularly in a school setting, the need for teachers commitment cannot be overemphasized because with the absence of committed teachers, the school cannot materialize its objectives and goals particularly with regard to effective, efficient teaching and learning process.In supporting the assumption, Razak, Darmawan and Keeves (2009) note that quality education cannot be realized without the effort and contribution of dedicated and committed teachers. Furthermore, Graham (1996) states that teacher organizational commitment is a critical factor that affects effective teaching- learning processes in schools.

According to Firestone and Pennel (1993) and Firestone and Martinez (2007), before effective organizational commitment is applicable in a work place, at least six factors must to be addressed and these are: teacher autonomy and efficacy, participation, feedback, collaboration, learning opportunities and resources. Graham (1996) notes, teachers who experienced most of these factors exhibits higher organizational commitment compared to those who do not. Furthermore, Harris (2008a, 2008b) states that, if the goal of reform is to create a conducive learning environment for the students, then it is worth noting that teachers equally require an enabling environment that promotes hard work, acceptance of challenging tasks, risk taking and promotion of growth.

\section{Mediating Role of Teacher Empowerment (TE)}

In general, empowerment is about the impression amongst members of the organization about their own organization, rather than something that management does to the employees (Dee, Henkin and Duemer 2002). Furthermore, Renihan and Renihan (1992) viewed empowerment as availing teachers and students with opportunities to give their input for decision making in specific situations that really matters which will ultimately lead to the shaping of organizational goals.Ripley and Ripley (1992), argue that empowerment is a process of granting members of the organization to carry out decision making or approval the power where normally such power was the prerogative of those at the helm of affairs. It is not a case where the management and leadership surrenders the power to their subordinates but it is only modifying and changing the way that control is put to use in the organization (Ripley and Ripley, 1992).

Empowerment also has been found to reinforce the factors such as knowledge, autonomy, feedback and importance that enable the employees to function effectively in his/their work place (Dee et al., 2002). In addition some of these factors such as knowledge and importance have been found to influence employee commitment in the organization (Bogler and Somech 2004). Moreover, Krishna (2007) also found that goal internalization and perceive control (subscales of empowerment) have influence on affective and normative commitment. Knowing the concepts and factors of empowerment, the second research question is to seek the strength of the mediating role of TE against the relationship between the DL and TC.

\section{Purpose and Framework of the Study}

Pursuant to the previous discussion, the main purpose of the study is to investigate the relationship and influence between distributed leadership (DL) and teacher's organizational commitment (TC) in selected secondary schools in Katsina State, Republic of Nigeria. The study also is trying to investigate if teacher empowerment (TE) variable will in some way mediates the relationship between the $\mathrm{DL}$ and TC. Transforming the research purpose to research question $(\mathrm{RQ})$, the study generates the RQs and hypotheses (HPs) such as follows:

$R Q 1:$ Is there a direct and significant relationship between $D L$ and $T C$ ?

HP1: There is a direct and significant relationship between DL and TC.

RQ2: Does TE mediate the relationship between $D L$ and TC?

HP2: TE mediates the relationship between DL and TC.

Figure 1 below demonstrates the framework of the study and the details of the hypothesized relationships between the variables understudy, DL, TC and TE. 
Figure 1: Conceptual Framework of the study.

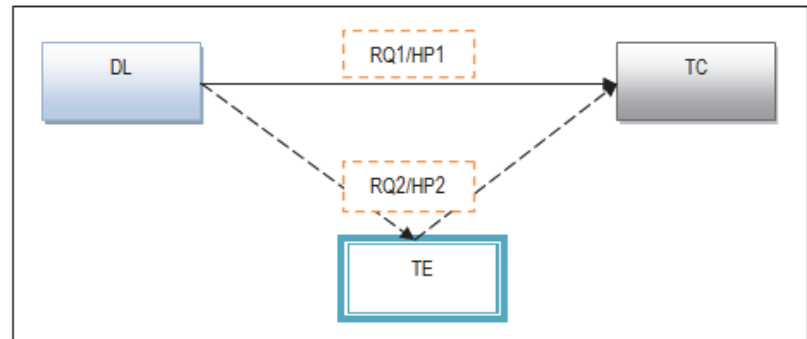

The quest for highly eminent committed teachers in Katsina State, Republic of Nigeria's secondary schools where effective teaching and learning can take place is so significant since without committed teachers the goal of quality education can hardly be realized. Therefore it is relevant and appropriate to emphasize on investigating the influence and relationship of school distributed leadership on teachers' commitment and also to explore if teachers' empowerment mediates the relationship between distributed leadership and teachers' commitment. Moreover, another objective of the study is to find out how the findings of the study implicates on the efforts of the stakeholders to improve the quality of education in Katsina State in particular and Republic of Nigeria in general.

\section{Methodology}

\subsection{Research design and instrumentation}

The study was fully committed to the survey method in collecting the primary data from the respondents (schools and teachers). Statistical Package for Social Science (SPSS) and Analysis of Moment Structures (AMOS versions 16.0) were employed in analyzing the data obtained. The advantages of AMOS computer software enabled the study to conduct the confirmatory factor analysis (CFA) and estimation of the hypothesized model of the study. All these are part and parcel of full fledge structural equation modeling (SEM). SEM was employed because SEM is the only analysis that allows complete and simultaneous tests of all the relationships (Ullman, 2007).

The study decided to determine, adopt and adapt all three instruments employed in this study. The instruments are; organizational commitment questionnaire (OCQ), distributed leadership inventory (DLI) and teacher empowerment scale (TES). The instruments were adopted from Mowday et al. (1979), Hulpia et al. (2010a and 2010b), Devis (2009) and Sprietzer (1995) respectively. The Mowday et al. (1979) short version of organizational commitment questionnaire consists of nine positively worded items and is uni-dimensional. The adoption of the version was informed by its simplicity to respondents and the fact that the psychometric properties of the long and short versions of the instruments are almost the same (Mowday et al 1979). The distributed leadership inventory was a five dimensions scale. The dimensions are: cooperation of leadership team, participative decision making, principal leadership, teacher leadership, and artifacts. The first three components were adopted and adapted from Hulpia et al. (2010a and 2010b) and the last two were adopted and adapted from Devis (2009).In total, the distributed leadership inventory consist of 31 items. Spreitzer's (1996) Teacher empowerment scale consists of four dimensions namely meaning, impact, self determination and competence. The dimensions are measured by twelve indicators, with three indicators measuring each of the four dimensions of empowerment. All three instruments were rated on 7 points Likert scale where: $1=$ strongly disagree (SLD), $2=$ moderately disagree (MLD), 3 = slightly disagree $(\mathrm{SD}), 4=$ neither agree nor disagree $(\mathrm{N}), 5=$ slightly agree $(\mathrm{SLA}), 6=$ moderately agree (MLA) and 7 = strongly agree (SA).

\subsection{Data collection and handling}

The survey instruments were administered to seven hundred and fifty (750) teachers from both junior and senior secondary schools in Katsina State, Republic of Nigeria. Five hundred and fifty (550) or $73 \%$ of the questionnaires were returned, out of which thirty seven (37) or $6.5 \%$ of the questionnaires contain serious missing information. The study then decided to exclude the data set for this study prior to analysis (Creswell 2010, Sekaran \& Bougie 2010). Further investigation led to the exclusion of another fourteen (14) set of returned survey questionnaires due to multivariate outliers. The final remaining survey questionnaires ready for further datatreatments were four hundred and ninety nine (499). 


\subsection{Demographic background}

Table 1 below exhibits the characteristics background of the respondents. The respondents were the teachers of junior and senior secondary schools in Katsina State, Republic of Nigeria. Three hundred and thirty six (336) or $67.3 \%$ of the respondents were male while one hundred and sixty three (163) or $32.7 \%$ of the respondents were female. According to age class, one hundred and eighty nine (189) or $37.9 \%$ are between twenty to thirty years, one hundred and fifty five (155) or $31.9 \%$ are between thirty one (31) to forty years (40) while one hundred and fifty five (155) or $31.9 \%$ are above forty (40) years. The age of the respondents ranged from 20 to 62 years with an average of 35 years. Furthermore, Table 1 also exhibits that one hundred and ninety three (193) or 38.7\% of the respondents possessed 1-5 years working experience, one hundred and sixty one (161) or 32,3\% possessed 6-10 years working experience and one hundred and forty five (145) or $29.1 \%$ possessed more than 10 years working experience. Moreover, the working experience of the respondents ranged from 1- 35 years with an average of 9 years.

Table 1: Demographic Background of Respondents

\begin{tabular}{|c|c|c|c|}
\hline Demographic Components & Characteristics & Frequency & Percentage \\
\hline \multirow[t]{2}{*}{ Gender } & $\begin{array}{c}\text { Male } \\
\text { Female }\end{array}$ & $\begin{array}{l}336 \\
163\end{array}$ & $\begin{array}{l}67.3 \% \\
32.7 \%\end{array}$ \\
\hline & Total & 499 & $100 \%$ \\
\hline \multirow[t]{2}{*}{ Age } & $\begin{array}{c}20-30 \\
31-40 \\
41+\end{array}$ & $\begin{array}{l}189 \\
155 \\
155\end{array}$ & $\begin{array}{l}37.9 \% \\
31.9 \% \\
31.9 \%\end{array}$ \\
\hline & Total & 499 & $100 \%$ \\
\hline \multirow[t]{2}{*}{ Working Experience } & $\begin{array}{c}1-5 \\
6-10 \\
11+\end{array}$ & $\begin{array}{l}193 \\
161 \\
145\end{array}$ & $\begin{array}{l}38.7 \% \\
32.3 \% \\
29.1 \%\end{array}$ \\
\hline & Total & 499 & $100 \%$ \\
\hline
\end{tabular}

\subsection{Statistical analyses}

The study was unequivocal in employing descriptive statistics, principal component analysis (PCA), confirmatory factor analysis (CFA) and structural equation modeling (SEM) for its data analyses. Descriptive statistics was purposely used in data screening and the analysis of demographic data of the respondents, PCA was used to reduce the items and obtained the marker variables that were used in subsequent analysis (Tabachnick and Fidel, 2010).CFA was used to assess the psychometric properties of the scales while SEM was employed to investigate the relationship between the exogenous and endogenous variables. The ultimate selection of SEM in conducting the analyses was due to its effectiveness compared to other multivariate techniques in establishing multiple dependant relationship between variables simultaneously (Hoe, 2008). To conclude, SPSS version (16.0) was employed in for descriptive statistics and PCA, while AMOS version (16.0) was employed for CFA and SEM.

\section{Results}

\subsection{Principal Component Analysis (PCA) of underlying factors for DL, TC and TE.}

The instruments used in this study were adopted and adapted and their owners have established their psychometric properties in different occasions. Therefore the main reason of conducting PCA here is only to reduce the number of indicators so as to extract marker variables (Tabachnick and Fidell, 2010), that will be used for CFA and subsequent analyses. Moreover, it has been argued that if instruments validity and reliability has been established, the researcher can proceed with other analysis without necessarily conducting EFA (Pallant, 2007).

\subsection{School distributed leadership}

Principal component analysis with varimax rotation using was conducted on each of the five factors that were hypothesized to be the factors of distributed leadership. All five factors that were analyzed possessed eigenvalues greater than one, and variance explained ranging from 48.9 to $63.6 \%$ of total variance.It should be noted that nineteen (19) variables loaded strongly on these factors. Table 2 below shows the factors and the indicators loaded to each 
component. In general, all indicators loaded satisfactorily $(>.5)$ to it is respective component. The loading ranges from .57 to .87 , for cooperation of leadership team and teacher leadership components respectively. The five factors were named, cooperation of leadership team (COLT), participative decision making (PDCM), principal leadership (PRIN.L), artifacts (ART) and teacher leadership (TCH.L). On reliability basis of the factors retained, Cronbach's alphas of all five factors of distributed leadership were good and within the threshold values of $\geq .7$ set for this study. The reliability indices of the five factors ranging from .85 to .80 which means much better compared to the standard threshold values.

Table 2: School Distributed Leadership (DL) Factor Loadings, Cronbach's alpha, KMO, BTS and \% of Variance Explained

\begin{tabular}{|c|c|c|c|c|c|c|c|c|c|}
\hline ITEM NO & COLT & PDCM & PRIN.L & $\overline{A R T}$ & $\overline{T C H} . \mathrm{L}$ & $a$ & $\mathrm{KMO}$ & BTS & $\%$ of $V E$ \\
\hline $\begin{array}{l}1 \\
2 \\
3 \\
8 \\
4\end{array}$ & $\begin{array}{l}.760 \\
.742 \\
.718 \\
.712 \\
.710\end{array}$ & & & & & .83 & .91 & .000 & 49.5 \\
\hline $\begin{array}{l}14 \\
15 \\
16 \\
13 \\
\end{array}$ & & $\begin{array}{l}.824 \\
.760 \\
.748 \\
.744 \\
\end{array}$ & & & & .81 & .85 & .000 & 53.2 \\
\hline $\begin{array}{l}30 \\
31 \\
28 \\
27\end{array}$ & & & $\begin{array}{l}.847 \\
.834 \\
.797 \\
.759\end{array}$ & & & .84 & .83 & .000 & 63.6 \\
\hline $\begin{array}{l}17 \\
18 \\
19 \\
20 \\
\end{array}$ & & & & $\begin{array}{l}.844 \\
.822 \\
.794 \\
.716 \\
\end{array}$ & & .80 & .78 & .000 & 63.2 \\
\hline $\begin{array}{l}23 \\
22\end{array}$ & & & & & $\begin{array}{l}.766 \\
.757\end{array}$ & .85 & .74 & .000 & 48.9 \\
\hline
\end{tabular}

\subsection{Teacher commitment}

A principal component analysis was conducted on Mowday et al. (1979). By employing the varimax rotation, it resulted with the extraction of only one factor. The factor accounted for $55 \%$ of variance explained and 4.99 eigenvalue. In addition the Bartlett's Test of Sphericity (BTS) was statistically significant ( $p=.000)$, while Kaiser Meyer-Olkin (KMO), measure of sampling adequacy was .92 and the correlation among the indicators was within the cutoff point of $\geq .30$ which is recommended by Tabachnick and Fidel (2010).Furthermore the Cronbach's alpha of the factor was .89, which is good and larger than the threshold value of $\geq .70$ (Pallant, 2007). Table 3 below exhibits the loadings, Cronbach's alpha, $\mathrm{KMO}, \mathrm{BTS}$, variance explained by the factor extracted among others.

Table 3: Teacher Commitment (TC) Factor loadings, Cronbach's alpha, KMO, BTS and \% of Variance explained

\begin{tabular}{cccccc}
\hline ITEM & LOADINGS & $\alpha$ & KMO & BTS & \% of V E \\
NO. & .821 & & & & \\
\hline 6 & .777 & & & & \\
2 & .766 & .89 & .92 & .000 & \\
8 & .766 & & & & \\
4 & .764 & & & \\
10 & .733 & & & \\
5 & & & & & \\
\hline
\end{tabular}

\subsection{Teacher empowerment}

The study conducted PCA with varimax rotation for each of the four factors hypothesized as components for teacher empowerment, using the data collected from the teachers of secondary schools in Katsina State, Nigeria. Twelve (12) indicators loaded on to four hypothesized factors, i.e. three indicators each for each component. Table 4 below shows the factor loading, for each indicator as well as the variance explained, KMO, reliability among others for each factor 
hypothesized to measure the teacher empowerment model. On reliability of the factors, Cronbach's alpha coefficient of the four factors were good and within the threshold of $\geq$.7. The reliability indices of the four factors extracted was .71, .70, .70 and .76 for impact, self-determination, competence and meaning respectively.

Table 4: Teacher empowerment (TE) Factor loadings, Cronbach's alpha, KMO, BTS and \% of variance explained

\begin{tabular}{|c|c|c|c|c|c|c|c|c|}
\hline ITEM & IMP & SELF. D & COMP & MEA & $\alpha$ & KMO & BTS & $\%$ of $V E$ \\
\hline 1 & .858 & & & & & & & \\
\hline 2 & .806 & & & & .71 & .636 & .000 & 63.6 \\
\hline 3 & .723 & & & & & & & \\
\hline 6 & & .817 & & & & & & \\
\hline 7 & & .807 & & & .70 & .673 & .000 & 63.6 \\
\hline 8 & & .768 & & & & & & \\
\hline 11 & & & .841 & & & & & \\
\hline 12 & & & .803 & & .70 & .644 & .000 & 62.5 \\
\hline 13 & & & .723 & & & & & \\
\hline 16 & & & & .861 & & & & \\
\hline 17 & & & & .820 & .76 & .683 & .000 & 68.0 \\
\hline 18 & & & & .794 & & & & \\
\hline
\end{tabular}

\subsection{Confirmatory Factor Analysis (CFA) estimation of measurement models for DL, TC and TE}

To confirm the underlying factors of the latent variables (DL, TC and TE), confirmatory factor analysis (CFA) with maximum likelihood (ML) estimation (Byrne 2010) was run to estimate the measurement model of DL, TC and TE using AMOS Version 16.0. The results of the CFA are exhibited by Table 5 below. As for DL measurement model, the results of the analyses exhibits that all estimated values are within the threshold values as recommended by scholars such as, Byrne (2010) and Hair et al. (2010): CMIN/DF = $2.70(\leq 5.0)$, RMSEA $=.059(\leq .08), \mathrm{CFI}=0.918(\geq 0.9), \mathrm{TLI}=0.933(\geq$ $0.9), \mathrm{GFI}=0.918(\geq 0.9)$, Chi-Square $(\mathrm{CMIN})=389.250, \mathrm{P}$ value $=.000$. Furthermore, for TC measurement model, the results of the analyses also exhibits that all estimated values are within the threshold values: CMINDF $=2.58(\leq 5.0)$, RMSEA $=.056(\leq .08), \mathrm{CFI}=.989(\geq 0.9), \mathrm{TLI}=.98(\geq 0.9), \mathrm{GFI}=.984(\geq 0.9)$, Chi-Square $(\mathrm{CMIN})=23.238, \mathrm{P}$ value $=$ .006. Lastly, for TE measurement model, the results of the analyses also exhibits that all estimated values are within the threshold values such as: CMINDF = $3.7(\leq 5.0)$, RMSEA $=.074(\leq .08), \mathrm{CFI}=.930(\geq 0.9), \mathrm{TLI}=.903(\geq 0.9), \mathrm{GFI}=$ $.947(\geq 0.9)$, Chi-Square $(\mathrm{CMIN})=179.40, \mathrm{P}$ value $=.000$.

Table 5: CFA results of DL, TC and TE measurement models

\begin{tabular}{|c|c|c|}
\hline Measurement Models for: & CFA Results & Threshold Values \\
\hline DL & $\begin{array}{l}C M I N / D F=2.70 \\
R M S E A=.059 \\
C F I=0.918 \\
T L I=0.933 \\
\text { GFI }=0.918 \\
\text { Chi-Square }(C M I N)=389.250 \\
P \text { value }=.000\end{array}$ & \\
\hline TC & $\begin{array}{l}\text { CMINDF }=2.58 \\
R M S E A=.056 \\
C F I=.989 \\
T L I=.98 \\
\text { GFI }=.984 \\
\text { Chi-Square }(C M I N)=23.238 \\
P \text { value }=.006 \\
\text { CMINDF }=3.7 \\
\text { RMSEA }=.074 \\
C F I=.930 \\
T L I=.903 \\
\text { GFI }=.947 \\
\text { Chi-Square }(C M I N)=179.400 \\
P \text { value }=.000\end{array}$ & $\begin{array}{c}\mathrm{CMIN} / \mathrm{DF} \leq 5.0 \\
\mathrm{RMSEA} \leq 0.08 \\
\mathrm{CFI} \geq 0.9 \\
\mathrm{TLI} \geq 0.9 \\
\mathrm{GFI} \geq 0.9\end{array}$ \\
\hline
\end{tabular}




\subsection{Development and specification of measurement and structural models of the study}

In order to get a good fitting structural model, the study resolved to specify the measurement model of the latent variables of the study first before attempting to specify the hypothesized structural model. It has been argued that once the measurement model is specified and fitted well, fitting of the overall structural model will be easier (Hair, et al. 2010). Figure 2 below exhibits the overall measurement model of the latent constructs of the study.

The hypothesized measurement model was assessed and estimated using a full fledge Structural Equation Modeling computer software AMOS Version 16.0. The model was also estimated using MLE with several key fit indices particularly the CMIN/DF, CFI, RMSEA, TLI and GFI, among others. The CMIN exhibits a value of 211.410 and $P=.000$ indicating a statistical significance. Although a model fit based on chi-square should not be statistically significant (in SEM), however, it has been argued that chi-square is usually affected by sample size (Tabachnick \& Fidel, 2010). By inspecting other key fit indices such as CMIN/DF $=2.47$, RMSEA $=.054, \mathrm{CFI}=.949, \mathrm{GFI}=.943$ and $\mathrm{TLI}=.938$, they indicated that the measurement model of the latent variables fit the data very well as all the fit indices were above the threshold values (Byrne, 2010; Hair et al. 2010). It was also argued that the fitting of the measurement model to the data would pave a way for fitting the structural model (Hair et.al. 2010).

Figure 2: Estimation of the Measurement Model of the Study

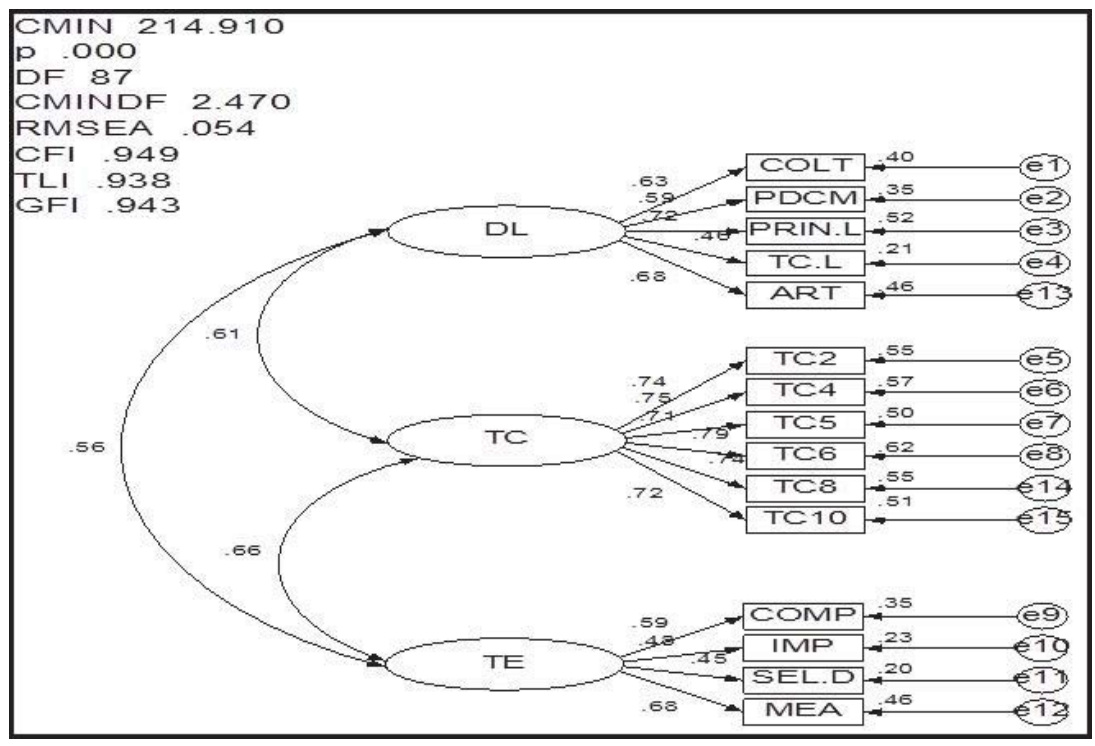

Following the successful fitting of the measurement models (as exhibited by Figure 2), it is assumed that fitting of the structural model of the study will not be a difficult job. Based on the theoretical framework couple with the empirical findings, the structural relationships among the latent variables used to assess the measurement model below were assessed and estimated based on MLE and several key goodness-of fit indices such as CMIN/DF, RMSEA, CFI, TLI and GFI. The estimated and specified structural model of the study will be used to answer and test the research questions and the research hypotheses respectively. Figure 3 below depicted the generated hypothesized structural model of the study.

An investigation of the generated hypothesized model of the study goodness-of- fit indices below, indicated that the chi-square was significant $(\mathrm{CMIN}=214.910)$ and the $P$ value $=.000$ of the chi-square ought to be insignificant to indicate good fit.However, taking into consideration the fact that chi-square is affected by large sample size $(>400)$ used in this study the result is not unexpected. Furthermore, other fit indices indicated that the model fit the data fairly well. This was established with a CMIN/DF $=2.47$ which is smaller than the threshold value of 5 that usually used in SEM literature (Hair et al. 2010). The RMSEA $=.054$ which is smaller than the threshold of $\leq .08$ set for this study indicated a good fitting model. The values of goodness-of-fit indices such as CFI $=.949, \mathrm{TLI}=.938$ and GFI $=.943$ are all within the threshold values set for this study indicated that the model fit the data well. It should also be noted that the overall fit of the measurement models and the structural model of the study are almost the similar. This signifies the fact that the structural model fit the data very well (Hair et al. 2010). 
We should bear in mind that in assessing the hypothesized structural model validity, employing the fit indices are not the only criteria as there is requirement for checking the path coefficients and loading estimates to determine if they are within the acceptable range (Hair et al. 2010). Furthermore, Hair et al. argued that a structural model is regarded as valid if the parameter estimates are statistically significant and in the direction earlier as predicted that is if the value is above zero it indicates a positive relationship while below zero, it indicates a negative relationship.

An inspection of the generated hypothesized structural model of the study in Figure 3 indicated that all the parameter estimates are statistically significant and flow in the direction as predicted. The finding reveals that there is a statistically direct significant relationship between DL and TC (standardized coefficient $=.34$ ) hence supports Hypothesis I. The result is inline with earlier findings by Hulpia and Devos (2010a) and Hulpia et al. (2010b). Moreover, the study also reveals the influence of mediating variable TE at certain degree on the relationships between DL and TC. This resulted an indirect significant relationship between $\mathrm{DL}$ and $\mathrm{TC}$ with a standardized coefficient $=.26$. In addition the total effect of DL on TC is .60 (standardized coefficient). Hence, the result evidently supports Hypothesis 2 of the study.

Figure 3: The generated hypothesized structural model of the study.

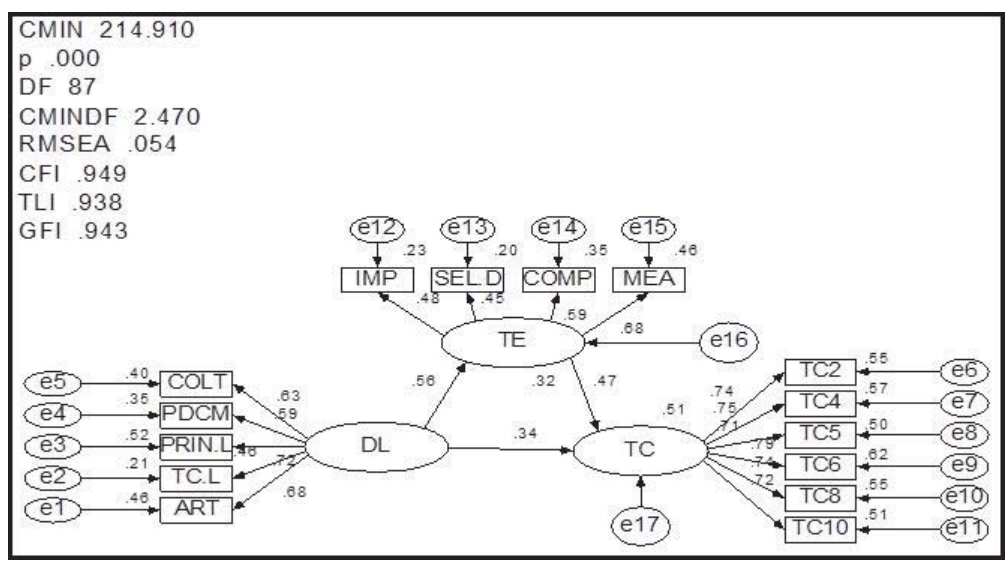

\section{Discussion and Implication}

The present study was designed to examine and investigate the influence of DL on secondary school's TC.In addition the study also examined the mediating effect of TE on the relationships between DL and TC. The data collection was conducted using the distributed leadership inventory (Hulpia et al., 2010a), organizational commitmentquestionnaire (Devis, 2009) and Mowday et al. (1979), and teacher empowerment scale (Spreitzer, 1996).CFA was conducted on the data collected and the results found were relatively in line with the results found by the owners of the instruments or scales. For the realizations of the above objectives, two research questions and two research hypotheses were developed and listed as follows:

$R Q 1:$ Is there a direct and significant relationship between $D L$ and $T C$ ?

HP1: There is a direct and significant relationship between DL and TC.

$R Q 2:$ Does TE mediate the relationship between $D L$ and TC?

HP2: TE mediates the relationship between DL and TC.

As for the purpose of answering RQ1 and testing the HP1, we are directing the discussions towards the information offers and exhibited by Figure 3 above. Here, DL is measured by five indicators such as COLT, PDCM, PRIN.L, TC.L and ART while TC is measured by six indicator items (TC2, TC4, TC5, TC6, TC8, and TC10). All indicators for these latent variables (DL and TC) were signified by high loadings and these would help to ensure the close relationships between these latent variables. As exhibited, it is obviously clear that DL has a direct and significant relationship on TC as indicated by a high standardized coefficient value .34. Hence the study had successfully resolved RQ1 and proved that HP1 was supported. It is worth to mention that the result supports earlier findings by Hulpia et al. (2010a), and Hulpia and Devos, (2010b) on the relationship between DL and TC. So, it is importance to formulate a statement that as far as the schools in Katsina State, Republic of Nigeria are concerned, the study proved that the school 
distributed leadership practice managed to have significant effect (at certain degree level) on teachers commitment as indicated by a considerable high standardized coefficient value of .34.

The study also attempted to investigate the effect and influence of the mediating variable, TE on the relationship between DL and TC as stated by RQ2. In this case TE is measured by four indicators; IMP, SEL. D, COMP and MEA. The validity and reliability status of TE measurement model is undeniable as it is signified by considerable loading values of every indicators of TE. As exhibited by Figure 3, mediator TE seems to influence the relationship between DL and TC. The results signified the direct effect is .34 (standardized) while indirect effect is .26 (standardized) and hence the total effect is .60 (standardized) which indicates that TE played its important role as a mediator. Hence, HP2 is supported. The study obviously proved that if considerable empowerment given to the teachers of the schools in Katsina State of Nigeria, this may leads to high teacher organizational commitment. The findings of this study support previous studies such as Bogler and Somech (2004) and Gaziel (2009). It is worth stressing that although the studies on the mediating effect of teacher empowerment were relatively few, however, there were many studies conducted on the effect of empowerment on teachers' commitment.

The findings from this study lead to both theoretical and practical implications. First and foremost, the finding of the study successfully enriched the existing literature as it was replicated in Africa in general and Nigeria in particular.We can say that there is some added value to the distributed leadership body of indigenous knowledge in the African continent, at least in Katsina State of Nigeria. In terms of practical implication, the school leaders need to ensure that they distribute the roles of leadership among the academics and staff so as to provide sufficient space for them to lead and to execute certain decisions at their own levels. Hence, distributing the roles of leadership among the teachers is in somewhat congruent to the concept of empowerment of the teachers and it was successfully that proved that it positively affect the teachers commitment. Without committed teachers, no meaningful progress can be achieved in addressing the challenges that the schools are facing (Hulpia et al., 2010b).

\section{Future Research and Conclusion}

This study is not without limitations and further research is needed. This study focused on public secondary schools; as such research that will incorporate private secondary schools should be conducted. Most probably there are going to be other new and interesting findings as it has been argued that school leaders in private schools are more likely to distribute leadership, compared to their counterpart in public schools (Spillane 2006; Spillane et. al. 2001, 2004). Moreover, further research should be conducted in elementary schools and also possibly tertiary institutions where the management structure is slightly different. Since the present study used a uni-dimensional construct dependant variable (organizational commitment), the future studies are recommended to employ other measures of organizational commitment with more than one dimension. As a conclusion, it is worth to mention that distributed leadership concept and theories are apparently and greatly contribute to the teachers' commitment because teachers (as followers) are the implementers of every decisions made by the leaders. Wrong decisions by leaders will definitely lead to wrong executions by the followers and hence the organization will suffer.

\section{References}

Adaeze, C.O. (2004). Educational Administration: Theory and Practice, Minna,Asodoc Ventures

Angelle, P. S. (2010). An organizational perspective of distributed leadership: A portrait of a middle school. ProQuest Education Journals, 33(5), 1-16.

Bass, B. (1985a). Leadership beyond expectations, The Free Press, New York, NY.

Bass, B. (1985b), Leadership and Performance Beyond Expectations, Harvard University Press, Cambridge, MA

Bass, B. and Avolio, B. (1993), "Transformational leadership: a response to critiques", in Chemers, M.M. and Ayman, R. (Eds), Leadership Theory and Research: Perspectives and Directions, Academic Press, San Diego, CA, pp. 49-80.

Bass, B. (1990), Bass and Stogdill's Handbook of Leadership, 3rd ed., The Free Press, New York, NY.

Bogler R. \&Somech A. (2004).Influence of Teacher Empowerment on TeachersOrganizational Commitment, Professional Commitment and OrganizationalCitizenship Behavior in Schools. Teaching and Teacher Education 20, 277-289.

Byrne, B. M. (2010). Structural Equation Modeling with AMOS: Basic Concepts, Applications and Programming, London, Routledge, Taylor and Francis Group

Creswell, J. W. (2010). Educational Research: Planning, Conducting, and Evaluating Quantitative and Qualitative Research, New jersey, Pearson Prentice Hall.

Devis, M. W. (2009). Distributed Leadership and School Performance. Unpublished Ph.D Thesis, George Washington University USA. 
Dee, J.R., Henkin, A.B. \& Duemer, I. (2002). Structural antecedents and psychological correlates of teacher empowerment, Journal of educational Administration, 41(3), 257-277.

Eacott, S. (2007). Strategy and practicing educational leader. Retrieved 03/01/2013.

Eacott, S. (2008). Strategy in educational leadership: in search for unity. JEA, Vol. 46, No. 3, pp. 353-75.

Eacott, S. (2010). Tenure, Functional track, and strategic leadership. International Journal of Educational Management, Vol. 24 (5), pp. 448-458.

Firestone, N.A. \& Pennel, J.R. (1993). "Teacher commitment, working conditions and differential incentive policies". Review of Educational Research, 63(4), 489-532

Firestone, W.A. and Martinez, M.C. (2007), "Districts, teacher leaders, and distributed leadership: changing instructional practice", Leadership and Policy in Schools, Vol. 6 No. 1, pp. 3-35.

Gaziel, H.(2009). Teacher empowerment and commitment at school based and non school based sites, In Zadja, J. and Gamage, D.T. (eds.). Decentralization school based management and quality, globalization, comparative education and policy research 8. Springer Science and Business Media BV.

Graham, K.C. (1996). Running ahead Enhancing Teacher Commitment, JOPERD, 67(1), 45-47.

Gronn, P. (2000), "Distributed properties: a new architecture for leadership", Educational Management and Administration, Vol. 28 No. 3 , pp. 317-38.

Gronn, P. (2002a), "Distributed leadership as a unit of analysis", The Leadership Quarterly, Vol. 13, pp. 423-51.

Gronn, P. (2002b), "Distributed leadership", in Leithwood, K. and Hallinger, P. (Eds), Second International Handbook of Educational Leadership and Administration, Kluwer Academic Publishers, Dordrecht, pp. 653-96.

Gronn, P. (2003), The New Work of Educational Leaders: Changing Leadership Practice in an Era of School Reform, Sage Publications, London.

Gronn, P. (2009), "Hybrid leadership", in Leithwood, K., Mascall, B. and Strauss, T. (Eds), Distributed Leadership According to the Evidence, Routledge, London.

Hair, J. F., Black, C. W., Babin, B. J. \& Anderson, R. E. (2010). Multivariate Data Analysis: A Global Perspective, New York, Pearson Prentice Hall.

Harris, A. (2004), "Distributed leadership and school improvement: leading or misleading?", Educational Management Administration \& Leadership, Vol. 32 No. 1, pp. 11-24.

Harris, A. (2007), "Distributed leadership: conceptual confusion and empirical reticence", International Journal of School Leadership, Vol. 10 No. 3, pp. 31-325.

Harris, A. (2008a). Distributed School Leadership, Developing Tomorrow's Leaders, London, Routledge.

Harris, A (2008b). Distributed leadership: according to the evidence. Journal of Educational Administration, 46(2). 172.

Hartley, D. (2010). Paradigms: How far does research in distributed leadership stretch? Educational Leadership and Management Journal, 38(3).

Hartley, D. (2007), "The emergence of distributed leadership in education: why now?", British Journal of Educational Studies, Vol. 55 No. 2, pp. 202-14.

Hoe, S.L. (2008). "Issues and procedures in adopting structural equation modeling technique". Journal of Applied Quantitative Method, $3(1)$.

House, R.J. and Adtiya, R.N. (1997), "The social scientific study of leadership: quo vadis?", Journal of Management, Vol. 23 No. 3, pp. 409-73.

Hulpia, H.\&Devos, G. (2010a). How distributed leadership can make a difference on Teachers organizational Commitment? A qualitative study, Teaching and Teacher Education, 26.

Hulpia, H., Devos, G., \&Keer, H. V. (2010b). The influence of Distributed Leadership on Teachers' Organizational Commitment: A Multilevel Approach.Journal of Educational research, Vol. 103, 40-52.

Krishna, Y. R., (2007). Psychological empowerment and organizational commitment. The Icfai journal of organizational behavior, Vol. $\mathrm{VI}(4)$ 153-180.

Leithwood, K. and Jantzi, D. (1999), "Transformational leadership effects: a replication", School Effectiveness and School Improvement, Vol. 4 No. 10, pp. 451-79.

Leithwood, K. and Jantzi, D. (2000a), "The effects of different sources of leadership on student engagement in school", in Riley, K. and Louis, K. (Eds), Leadership for Change and School Reform, Routledge, London, pp. 50-66.

Leithwood, K. and Jantzi, D. (2000b), "The effects of transformational leadership on organizational conditions and student engagement with the school", Journal of Educational Administration, Vol. 38 No. 2, pp. 112-29.

Leithwood, K., Day, C., Sammons, P., Harris, A. and Hopkins, D. (2006), Successful School Leadership: What it is and How it Influences Pupil Learning, NCSL/Dept for Education \& Skills, University of Nottingham Paul, Nottingham.

Leithwood, K., Mascall, B., Strauss, T., Sacks, R., Memon, N. and Yashkina, A. (2007), "Distributed leadership across schools, districts, and provincial governments: a search for effective patterns", paper presented at the AERA Conference, Chicago, IL, April.

Leithwood, K., Anderson, S., Mascall, B. and Strauss, T. (2010), "School leaders' influences on student learning: the four paths", in Bush, T., Bell, L. and Middlewood, D. (Eds), The Principles of Educational Leadership and Management, Sage Publications

Mascall, B.,Leithwood, K.,Straus, T.,\& Sacks, R. (2008). "The relationship between distributed leadership and teachers' academic optimism". Journal of Educational Administration. Vol. 46. No. 2. Pp. 214-228. 
Mowday, R. T. \& Steers R. M. \& Porter, L. W. (1979). The Measurement of Organizational Commitment. Journal of Vocational Behavior, $14,224-247$.

Mujis, D. (2011). Leadership and organizational performance: from research to prescription? International Journal of Educational Management. 25(1), 45-60.

Pallant, J. (2007). Survival Manual: A Step by Step Guide to Data Analysis using SPSS for Windows,New York, Open University Press.

Razak, N.A, Darmawan, I.G.N., \& Keeves, P.J. (2009). Teacher commitment, In Saha, L.J. \& Dworkin, A.G. (Eds.) International handbook of research on teachers and teaching, Springer Science, pp. 343-360.

Renihan, F. \& Renihan, P. (1992). Educational leadership: A renaissance Metaphor, Education, Canada, Spring.

Ripley, R. E. \& Ripley, M. J. (1992). Empowerment the corner stone of quality: Empowering management in innovative organizations in the 1990s, Management Decision,30(4), 20-43.

Sekaran, U \& Bougie, R (2010). Research Methods for Business: A skill building approach.United Kingdom, John Willey \& Sons Ltd.

Spillane, J., Halverson, R. and Diamond, J. (2001), "Investigating school leadership practice: a distributed perspective", Educational Researcher, Vol. 2001 No. 30, p. 23.

Spillane, J., Halverson, R. and Diamond, J. (2004), "Towards a theory of school leadership practice: implications of a distributed perspective", Journal of Curriculum Studies, Vol. 36 No. 1, pp. 3-34.

Spillane, J. P. (2006).Distributed leadership, San Francisco, Jossey-Bass.

Spreitzer, G. (1995). Psychological Empowerment in the work place, dimensions, measurement and validation. Academy of management Journal,35(5), 1442-65.

Stogdill, R. M. (1948). Personal factors associated with leadership. A survey of the literature, Journal of Psychology, 25, 35-71.

Stogdill, R.M. (1974). Handbook of leadership: a survey of theory and research: Free Press: NY.

Stogdill, R.M. (1982). Stogdill's handbook of leadership: a survey of theory and research revised and expanded (2nd Ed.) Macmillan, USA: NY.

Tabachnick, B. G., \&Fidell L. S. (2010). Using Multivariate Statistics, San Francisco, Pearson.

Ullman, J. B. (2006). Structural Equation Modeling: Reviewing the Basics and Moving Forward. Journal of Personality Assessment, 87(1), 35-50. 